\title{
The Seven Habits of Highly Effective People Who Want to Do Ecological Restoration
}

\author{
Steven N. Handel
}

W e're surrounded by do-gooders who write, lecture, post, and generally harangue us on how to be better people, partners, millionaires, and personal fitness champs. The New York Times even publishes a weekly bestsellers listing of advice books. But what about us? What nuggets can move us from being merely waterers of native plant seedlings to a movement that is playing its role in saving the world? What habits must be ingrained to keep us moving towards this oft-cited goal?

\section{Habit 1. Admit ignorance.}

Drop the conceit that you know everything about your site's physical and biological conditions, its varying hydrologic state, the long-term changes in community structure, and past land uses, which intrude on reasonable goals for your project. Expect many of the plants you installed to die. This is a routine outcome, not a failure. Almost no project has enough time to do background analysis to predict the stresses and constraints that will impinge on your habitat restoration plan. Be humble. Ignorance of every one of the site's needs free us to experiment with many plant palettes, many small scale ground plane interventions, and a chance to record the stochastic nature of the developing living world. Enjoy watching it unfold.

\section{Habit 2. Don't confuse the past with the future.}

The world is changing. It always has changed. Detailed knowledge of the literature describing the site's biota 100 years, or even 50 years, ago may be irrelevant in today's climate, landscape ecology, human interferences, and changing biodiversity. And after today's conditions, tomorrow's may be even more peculiar. We cannot predict the future so do not assume it will be like the past. It will not be like the past. Consider this another reason to nurture the humility which must grow within you.

Ecological Restoration Vol. 34, No. 3, 2016

ISSN 1522-4740 E-ISSN 1543-4079

(O2016 by the Board of Regents of the University of Wisconsin System.

\section{Habit 3. Celebrate Earth, Wind, and Fire.}

Nature is not static. Disturbance regimes vary in frequency, intensity, and duration. The past metrics for disturbances will change in the future (see Habit 2). Episodic events have enormous impact which can persist for decades. Yes, I know you've lived in your town for five years and know it well. Assume that the critical events happen every six years, and you really don't know at all what they will be. Do not lose your sense of wonder over the impact of landslides, windstorms, and wildfires. Things may have been quiet in your community the last few years, but nature can tell you a direct lie when she wants to.

\section{Habit 4. Welcome knowledge. Nerds rule.}

Our communities are full of people who traffic in rumor and superstition. They give us advice all the time. Nature will come back, some say, as if all the plants missing for the past few decades will magically disperse in, grow, and harbor all those animals that also have also been missing for those past few decades. Others will say that those invasive species that are rapidly diminishing our biodiversity aren't so bad after all. They are just different from the past; that's not so bad. Happily, there's a large group of hardworking people who do manipulative experiments and careful statistical analyses. Their writings can be dense and sometimes hard to follow, but they are peeling back the layers of ignorance towards a real understanding of how living plant and animal communities work. If our field is not fact based, it becomes a three-dimensional fairytale but there is no living happily ever after. Study restoration science.

\section{Habit 5. It takes a village. Build one.}

Our passion for the natural world and trying to improve it is very personal, as true love always is.

Restoration cannot succeed only by leadership by lone wolves. Like those wolves, the practice of restoration ecology requires a pack of workers. We need people with complementary skills, teammates. They keep our energy and enthusiasm high. We need people to do follow up 
maintenance, monitoring, and to push our local governments to nurture our projects after we have left the stage.

\section{Habit 6. Go tell it on a mountain.}

People forget. We need outreach to remind people why the project was done, why the project is valuable to us, and why care of the project is just as important as other community maintenance needs. Explaining ecological services and the dynamics of restored communities to neighbors and to governments at all levels is a continuous process. We live in an age when the variety of media outlets is enormous. Some or all of them are needed to keep telling people why the restoration was done in the first place. You should not forget that other people forget. This is not an insult, but the reality of human nature.

\section{Habit 7. Commit to a long-term relationship.}

Too many projects fail after few to several years as the original champions of the project move on or are promoted up or are forgotten by too busy administrators who themselves have moved on to the next great idea. We need continuity of effort. Build a long chain of enthusiasts for your project.

\section{A Challenge to Our Readers}

There must be more habits to add to this list! We invite our readers to submit their favorite habits to reach our title's goal. In your submission, include the habit and a short one paragraph description of that habit. The Editorial Office will publish ones that appear most cogent in the March 2017 issue. Entries that are published will win for the submitters a free SER t-shirt.

Submit your ideas to EReditor@aesop.rutgers.edu.

All entries must be received before November 1, 2016.

Someone has to keep the torch burning for your project into the far future. If you have not made plans for longterm care, maybe you shouldn't even start the project. If you can't keep your torch burning you may very well be making an ash of yourself.

\section{Recommended References}

Covey, S., 1989. The Seven Habits of Highly Successful People. New York, NY: Fireside/Simon \& Schuster.

Clewell, A., J. Rieger and J. Munro. 2005. Guidelines for Developing and Managing Ecological Restoration Projects, 2nd ed. Society for Ecological Restoration International. www.ser.org.

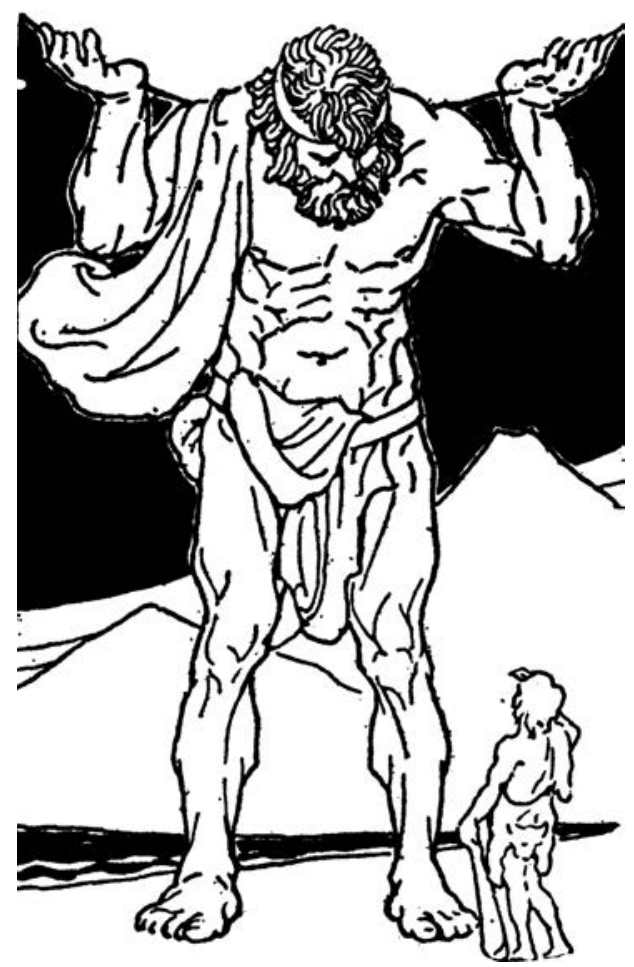

The Labors of Hercules. O.B. Miller.1920. The Treasure Chest of My Bookhouse. Chicago, IL: The Bookhouse for Children. fcit.usf.edu. 